\title{
Revision of the genus Halamphora (Bacillariophyta) in the Antarctic Region
}

\author{
Bart Van de Vijver ${ }^{1,2, *}$, Kateřina Kopalová ${ }^{3}$, Ralitsa Zidarova $^{4}$ \& Zlatko Levkov ${ }^{5}$
}

\begin{abstract}
${ }^{1}$ Botanic Garden Meise, Department Bryophyta \& Thallophyta, Nieuwelaan 38, BE-1860 Belgium
${ }^{2}$ University of Antwerp, Department of Biology, ECOBE, Universiteitsplein 1, BE-2610 Wilrijk, Belgium

${ }^{3}$ Charles University in Prague, Faculty of Science, Department of Ecology, Viničná 7, 12844 Prague 2, Czech Republic

${ }^{4}$ St."Kliment Ohridski” University of Sofia, Faculty of Biology, Department of Botany, 8 Dragan Tzankov Blvd., Sofia 1164, Bulgaria

${ }^{5}$ Institute of Biology, Faculty of Natural Sciences, Gazi Baba bb, 1000 Skopje, Republic of Macedonia

*Author for correspondence: vandevijver@br.fgov.be
\end{abstract}

\begin{abstract}
Background and aims - The limnoterrestrial and aquatic diatom flora of the entire Antarctic Region (subAntarctic islands, Maritime Antarctic Region, Antarctic Continent) is currently under revision. One of the genera that still needed a thorough analysis is the genus Halamphora, recently split off from Amphora. Halamphora species are a typical constituent of the lake diatom flora in the Antarctic region.

Methods - Using both Light Microscopical (LM) and Scanning Electron Microscopical (SEM) techniques, the morphology of a large number of Halamphora taxa, present in the samples from the Antarctic Region, has been analysed. Each taxon is properly described, illustrated and compared with other morphologically similar Halamphora taxa, known worldwide.

Key results - A total of seven Halamphora taxa has been found. Two taxa could be identified using the currently available literature: Halamphora veneta (Kütz.) Levkov and H. oligotraphenta (Lange-Bert.) Levkov. Five new Halamphora species are described: Halamphora ausloosiana Van de Vijver \& Kopalová sp. nov., H. compereana Van de Vijver \& Levkov sp. nov., H. dagmarobbelsiana Van de Vijver \& Levkov sp. nov., H. lateantarctica Van de Vijver, Kopalová, Zidarova \& Levkov sp. nov. and H. vyvermaniana Van de Vijver, Kopalová, Zidarova \& Levkov sp. nov.

Conclusions - The obtained results confirm the presence of a typical and highly specific limnoterrestrial diatom flora in the Antarctic Region and contradict the generally accepted idea about the worldwide distribution of diatoms.
\end{abstract}

Key words - Antarctic Region, Bacillariophyta, Halamphora, new species, morphology, taxonomy.

\section{INTRODUCTION}

The genus Halamphora (Cleve) Levkov was originally described by Cleve (1895) as a subgenus of Amphora Ehrenb. ex Kütz. In 2009, Levkov raised the subgenus to the genus level and recombined many Amphora taxa that presented all morphological features of the new genus to Halamphora. The genus is characterized by moderately to strongly dorsiventral valves with a shallow ventral mantle, uniseriate or biseriate striae comprised of round, elliptical to transversely elongated areolae occluded by hymenes, an eccentric raphe system and a girdle composed of numerous open copulae. Widespread species in this genus, often occurring in large abundances, are for instance all species belonging to the species complexes around the former Amphora veneta Kütz., A. coffeaeformis C.Agardh and A. normanii Rabenh.
In the Antarctic Region, almost all records of Halampho$r a$ species were attributed to $H$. (cf.) veneta (Kütz.) Levkov giving this presumably cosmopolitan species a very broad biogeographical distribution with records ranging from the Antarctic Continent to the sub-Antarctic islands in the southern Indian and Atlantic Oceans (Kellogg \& Kellogg 2002). It was however quickly clear that species drift and force-fitting (Tyler 1996) increased the taxonomic uncertainty about this presumably cosmopolitan species. A first superficial analysis of some of the Antarctic populations revealed distinct differences between some of these populations making a revision of the genus Halamphora in all parts of the Antarctic Region highly necessary, especially in the light of further biogeographical and ecological research.

In this paper, we present the first revised species list of the genus Halamphora present in Sub-Antarctic and Antarc- 
tic inland waters, compiled on the basis of a critical revision of literature reports (Kellogg \& Kellogg 2002) and, where necessary, (re)analysis of slides and samples from our own Antarctic collections (see table 1). Ile Amsterdam, although located just north of the sub-Antarctic Region is included as it is part of the French Antarctic Territories. Five new Halamphora taxa are described from aquatic materials. In addition, information is provided for two other, previously described, Halamphora taxa with notes on their morphology, ecology and biogeography.

\section{MATERIAL AND METHODS}

Samples used in this study were collected from different aquatic habitats during several field trips on the South Shetland Islands (Livingston Island), James Ross Island and the sub-Antarctic Islands in the southern Indian (Ile Amsterdam, Iles Crozet). Additional material from the Antarctic Continent (Bunger Hills and Vestfold Hills) was acquired in collaboration with Dr. J.A.E. Gibson (Gibson et al. 2006 and unpublished data). Details on sampling methods and physico-chemical analyses can be found in Van de Vijver et al. (2002), Gibson et al. (2006), Kopalová et al. (2013), Kopalová \& Van de Vijver (2013) and Chattová et al. (2014). All sampling localities are indicated on fig. 1 whereas all samples and slides used in the present study are listed in table 1 .

Diatom samples for LM observation were prepared following the method described in Van der Werff (1955). Subsamples of the original material were oxidized using $37 \%$ $\mathrm{H}_{2} \mathrm{O}_{2}$ and heating to $80^{\circ} \mathrm{C}$ for approximately $1 \mathrm{~h}$. The reaction was further completed by the addition of $\mathrm{KMnO}_{4}$. Following digestion and centrifugation (three times 10 minutes at $3700 \mathrm{xg}$ ), the material free of organic matter was diluted with distilled water for sample mounting to avoid excessive concentrations of diatom valves and frustules on the slides. A subsample from the organic-free material was mounted in Naphrax ${ }^{\circledR}$ for diatom community studies. The slides were analysed using an Olympus BX53 microscope, equipped with Differential Interference Contrast (Nomarski) and an Olympus UC30 digital camera. Samples and slides are stored at the BR-collection, property of the Belgian federal government and given in permanent loan to the Botanic Garden Meise (Belgium). For scanning electron microscopy (SEM), parts of the oxidized suspensions were filtered through a $1-\mu \mathrm{m}$ Isopore ${ }^{\mathrm{TM}}$ polycarbonate membrane filter (Merck Millipore). The stubs were sputter-coated with a Gold-Palladium layer of $20 \mathrm{~nm}$ and studied in a ZEISS Ultra SEM microscope at $3 \mathrm{kV}$ (Natural History Museum London, UK). Diatom terminology follows Ross et al. (1979), Round et al. (1990) and Levkov (2009). Comparisons with other Antarctic, South American and northern Hemisphere taxa, are based on Sabater et al. (1990), Carter \& Round (1993), Lange-Bertalot et al. (1996) and Levkov (2009).

\section{OBSERVATIONS}

A total of seven Halamphora taxa has been found in the samples collected from the investigated sub-Antarctic (including Ile Amsterdam) and Antarctic localities. Two of them could be identified up to species level using the currently available literature: Halamphora oligotraphenta (Lange-Bert.) Levkov and $H$. veneta. A complete morphological and ecological characterisation is provided below.

Five taxa are described as new for science. These are described below and compared with similar taxa from the Northern hemisphere and from South America.

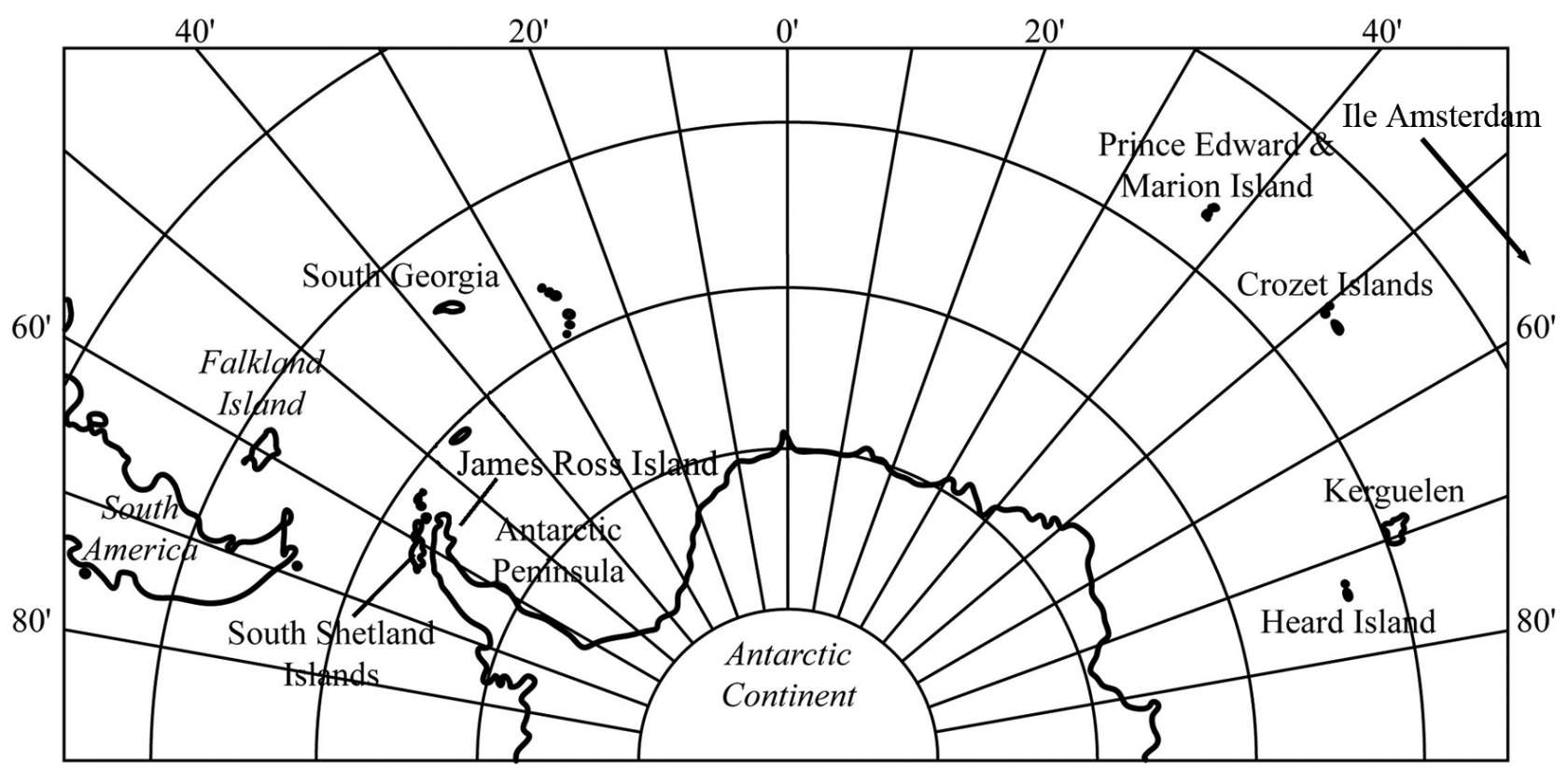

Figure 1 - The Antarctic Region with the location of the different islands and archipelagos discussed in this paper. Ile Amsterdam is positioned outside the map (arrow). 
Table 1 - List of samples used in this study.

\begin{tabular}{lll}
\hline Sample ID & Geographic locality & Source \\
\hline C-W581 & Crozet & Van de Vijver et al. 2002 \\
AMS-W121 & Ile Amsterdam & Chattová et al. 2014 \\
AMS-W033 & Ile Amsterdam & Chattová et al. 2014 \\
AMS-W041 & Ile Amsterdam & Chattová et al. 2014 \\
AMS-BM050 & Ile Amsterdam & unpublished data \\
SG-W369 & South Georgia & Van de Vijver \& Beyens 1996 \\
LIV-BY049 & Livingston Island & Kopalová \& Van de Vijver 2013 \\
LIV-BY055 & Livingston Island & Kopalová \& Van de Vijver 2013 \\
LIV-BY062 & Livingston Island & Kopalová \& Van de Vijver 2013 \\
JRI-032 & James Ross Island & Kopalová et al. 2013 \\
JRI-063 & James Ross Island & unpublished data \\
VH003 & Vestfold Hills (Ant. Continent) & unpublished data \\
VH005 & Vestfold Hills (Ant. Continent) & unpublished data \\
BH022 & Bunger Hills (Ant. Continent) & Gibson et al. 2006 \\
\hline
\end{tabular}

\section{Previously described taxa}

\section{Halamphora veneta (Kütz.) Levkov Figs 2 \& 3}

LM: morphological observations - Frustules elliptic with obtusely rounded ends (fig. 2O). Valves semi-lanceolate, dorsi-ventral with convex dorsal margin and slightly concave to straight ventral margin; valve apices rounded, weakly separated from the rest of the valve, sub-protracted and slightly ventrally bent; valve dimensions $(n=30)$ : length $13-38$ $\mu \mathrm{m}$, width 3.5-6.5 $\mu \mathrm{m}$, frustule width 9-13 $\mu \mathrm{m}$. Axial area narrow, wider on the ventral valve side. Central area on the dorsal side almost indiscernible, wider on the ventral side. Raphe sternum broad, gradually narrowing towards the valve ends; raphe biarcuate with straight to slightly dorsally bent proximal endings, slightly expanded into small central pores. In some specimens central pores distantly spaced (fig. 2A-D $\&$ O). Dorsal striae $22-26$ in $10 \mu \mathrm{m}$, distinctly punctate, radiate throughout, composed of round to elongated areolae. Ventral striae indistinct, hard to resolve in LM, 26-30 in 10 $\mu \mathrm{m}$.

SEM: morphological observations, external and internal view - Transition between dorsal valve side and dorsal mantle abrupt (figs 2R, 3B \& C). Narrow, thickened marginal ridge present along the junction of valve face and dorsal margin (figs 2Q, 3A \& B). Marginal ridge strongly thickened at the apices (figs 2R, 3B). In some specimens, raphe sternum ornamented with round or irregularly-shaped depressions, variable in size and not internally penetrating (fig. 3A-C). Internally, distal raphe endings slightly ventrally deflected and terminating onto developed helictoglossae (fig. 2S). Proximally, raphe terminating onto fused central helictoglossae (figs 2S, 3E). Dorsal striae uniseriate, interrupted at the marginal ridge and continuing onto the valve mantle (figs $2 \mathrm{R}$, $3 C)$. Ventral striae not interrupted near the central nodule, composed of one single rounded to elongated areola (figs 2P, 3D). Internally, areolae occluded by hymens (fig. 3E). Girdle bands open, each bearing at least one row of large, round poroids similar in size as the ventral areolae (fig. 2P).

Habitat and distribution - Despite the large number of literature records in (sub-)Antarctica (Kellogg \& Kellogg
2002: 33 records), Halamphora veneta s.s. was so far only confirmed from the sub-Antarctic islands Ile Amsterdam and Ile de la Possession in the southern Indian Ocean. The largest populations were found in rather alkaline $(\mathrm{pH}>7.5)$ lakes and pools with a moderately high conductivity value $(100-500 \mu \mathrm{S} / \mathrm{cm})$. Only a very few valves (<10 valves) were found in soils and wet mosses (Van de Vijver et al. 2002). On South Georgia, in the southern Atlantic Ocean, one small population was found in a small pool with a very alkaline $\mathrm{pH}(9.7)$ and low conductivity values $(>50 \mu \mathrm{S} / \mathrm{cm}$ ) (Van de Vijver \& Beyens 1996).

Taxonomical remarks - The population of $H$. veneta from Ile Amsterdam (fig. 3A-E) has a more prominent ornamentation of the raphe ledge, a higher stria and areola density than European (Hustedt 1930: 345, Levkov 2009: 242) and North American (Patrick \& Reimer 1975: 73) populations. However, all other dimensional, morphological and ultrastructural features fit entirely with the description of $H$. veneta making conspecificity more than likely.

\section{Halamphora oligotraphenta (Lange-Bert.) Levkov} Figs $4 \mathrm{~A}-\mathrm{R} \& 5$

LM: morphological observations - Valves semi-lanceolate, dorsi-ventral with a convex dorsal margin and a straight to weakly tumid in mid-valve ventral margin. Valve apices protracted and slightly ventrally bent, capitate in larger specimens to rostrate in smaller specimens. Valve dimensions $(\mathrm{n}=$ 30): length 17-31 $\mu \mathrm{m}$, width 3.5-4.5 $\mu \mathrm{m}$. Axial area narrow, wider on ventral valve side. Central area absent on dorsal side, longitudinally elongated on ventral side. Raphe biarcuate, raphe branches slightly curved, with proximal endings weakly expanded and slightly dorsally deflected and distal fissures dorsally deflected. Dorsal striae with fine punctation in LM, radiate throughout, 26-30 in $10 \mu \mathrm{m}$. Ventral striae almost indistinct, hard to resolve with LM, 28-36 in $10 \mu \mathrm{m}$.

SEM: morphological observations, external and internal view - Transition between dorsal valve side and dorsal mantle abrupt (fig. 5B \& C). Narrow, very weakly developed marginal ridge present along junction of valve face and dorsal margin (fig. 5B). Raphe ledge flat, narrow, linear, slightly 

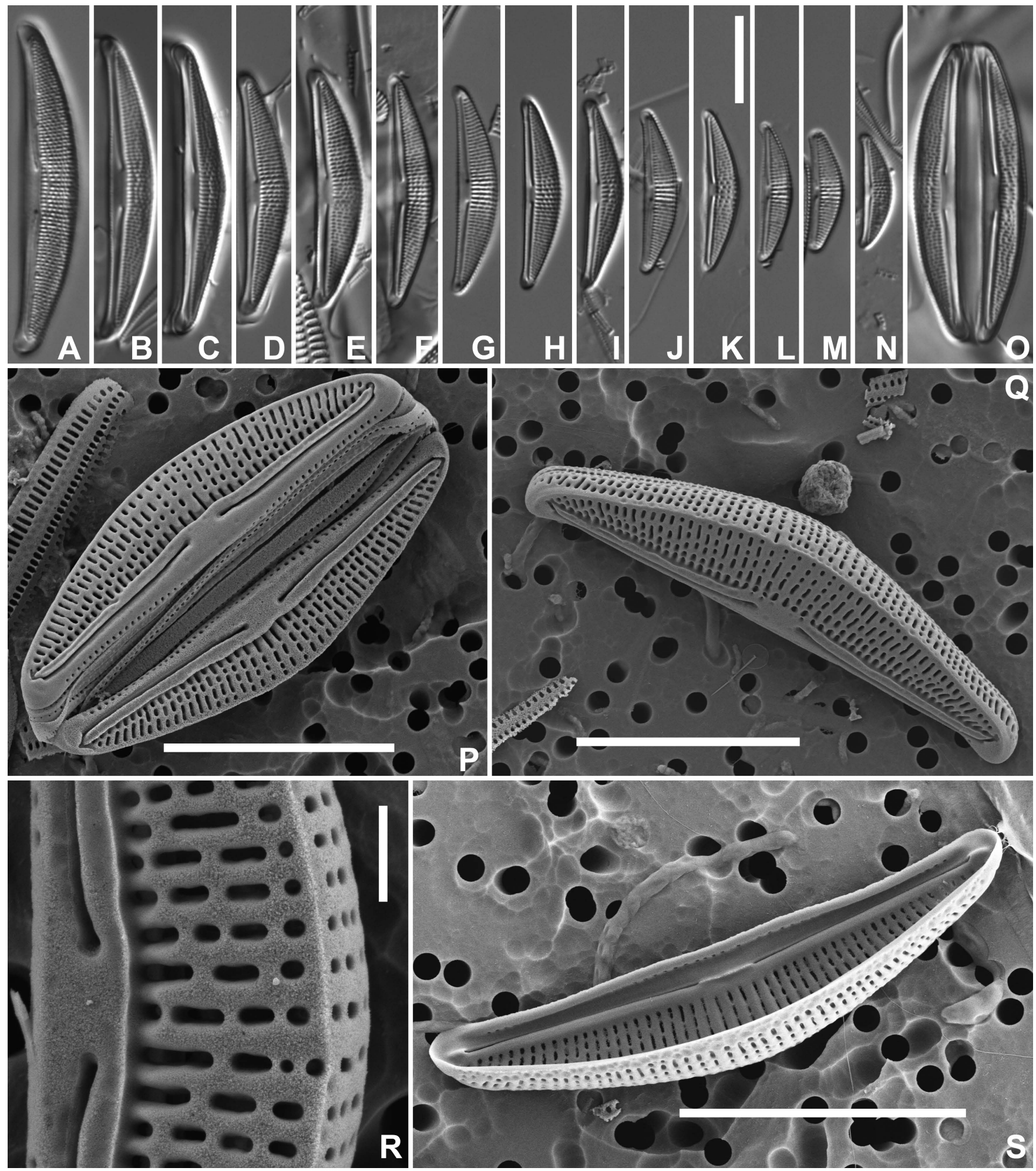

Figure 2 - Halamphora veneta: A-O, LM micrographs of largest population on Ile de la Possession (Iles Crozet) (sample C-W581). O represents a frustule in girdle view; P, Scanning electron micrograph (SEM), entire frustule showing two connected valves and some girdle elements; Q, SEM, entire valve in valve view; R, SEM, external detail of the central area; S, SEM, internal overview of an entire valve with the fused proximal helictoglossae. Scale bars represent $10 \mu \mathrm{m}$ except for $\mathrm{R}$ where scale bar $=1 \mu \mathrm{m}$. 


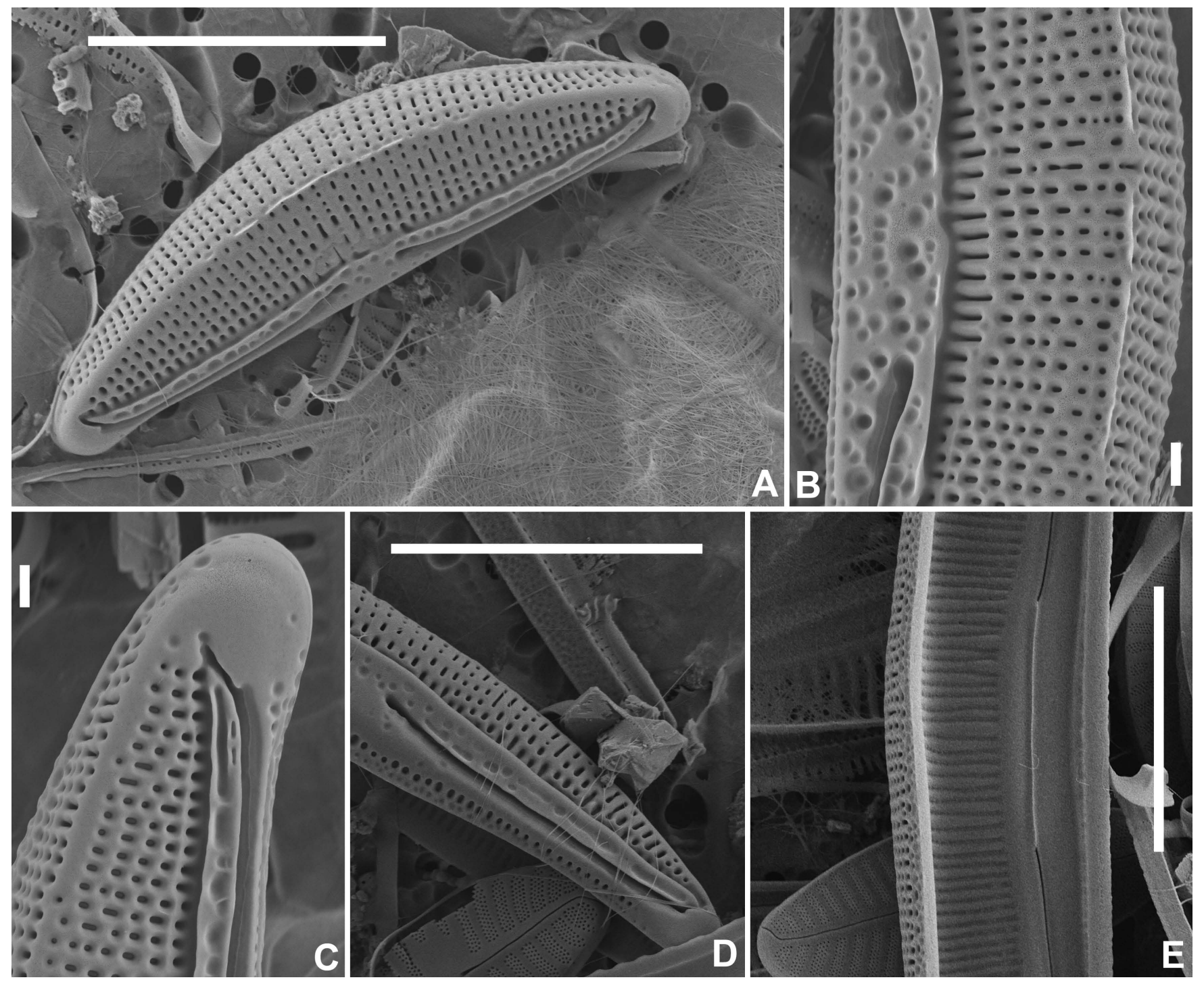

Figure 3 -Scanning electron micrographs (SEM) of the largest population of Halamphora veneta on Ile Amsterdam (sample AMS-W041): A, entire valve showing the ornamentation on the raphe ledge; B, external detail of the central area with the proximal raphe endings and the typical ornamentation; $C$, external detail of a valve apex showing the prominent raphe ledge; $D$, external detail of a valve apex in oblique view showing the mantle areolae; E, internal detail of the central area with fused helictoglossae. Scale bars represent $10 \mu \mathrm{m}$ except for B \& $\mathrm{C}$ where scale bars $=1 \mu \mathrm{m}$ and $\mathrm{E}$ where scale bar $=5 \mu \mathrm{m}$.

wider in mid-valve, without ornamentation (fig. 5A \& B). Internally (fig. 5G), distal raphe endings slightly ventrally deflected (fig. 5G), terminating onto developed helictoglossae. Proximally, raphe endings terminating onto fused central helictoglossae (fig. 5F). Dorsal striae uniseriate, composed of round to elongated areolae (fig. 5B \& C). Ventral striae continuing onto the valve mantle, not interrupted in the region of the central nodule, composed of round to elongated areolae (fig. 5A). Internally, areolae occluded by hymenes (fig. 5F).

Habitat and distribution - At present $H$. oligotraphenta is only confirmed from James Ross Island (Kopalová et al. 2012, 2013 as Amphora sp.) Reported populations from other Antarctic localities in the Maritime Antarctic Region need to be carefully examined using SEM to distinguish them from for instance Halamphora ausloosiana Van de Vijver \&
Kopalová sp. nov. (see below). The largest populations were found in lakes on Ulu Peninsula and Clearwater Mesa with a very alkaline $\mathrm{pH}$ (between 8.0 and 8.8 ) and rather low to high conductivity values (up to $1000 \mu \mathrm{S} / \mathrm{cm}$ ). In seepage areas and streams, the species, though present, was less frequently observed.

Taxonomical remarks - The populations of $H$. oligotraphenta from James Ross Island fit the protologue (Haworth 1974: 48, figs 6 \& 19) and share comparable morphological features as European (Lange-Bertalot \& Metzeltin 1996, Levkov 2009) populations. A small proportion of the analysed populations showed heavily silicified valves, the socalled ghost valves (figs 4Q \& R, 5E). It is unclear how and why these valves are formed. For the separation from $H$. ausloosiana, see below. 


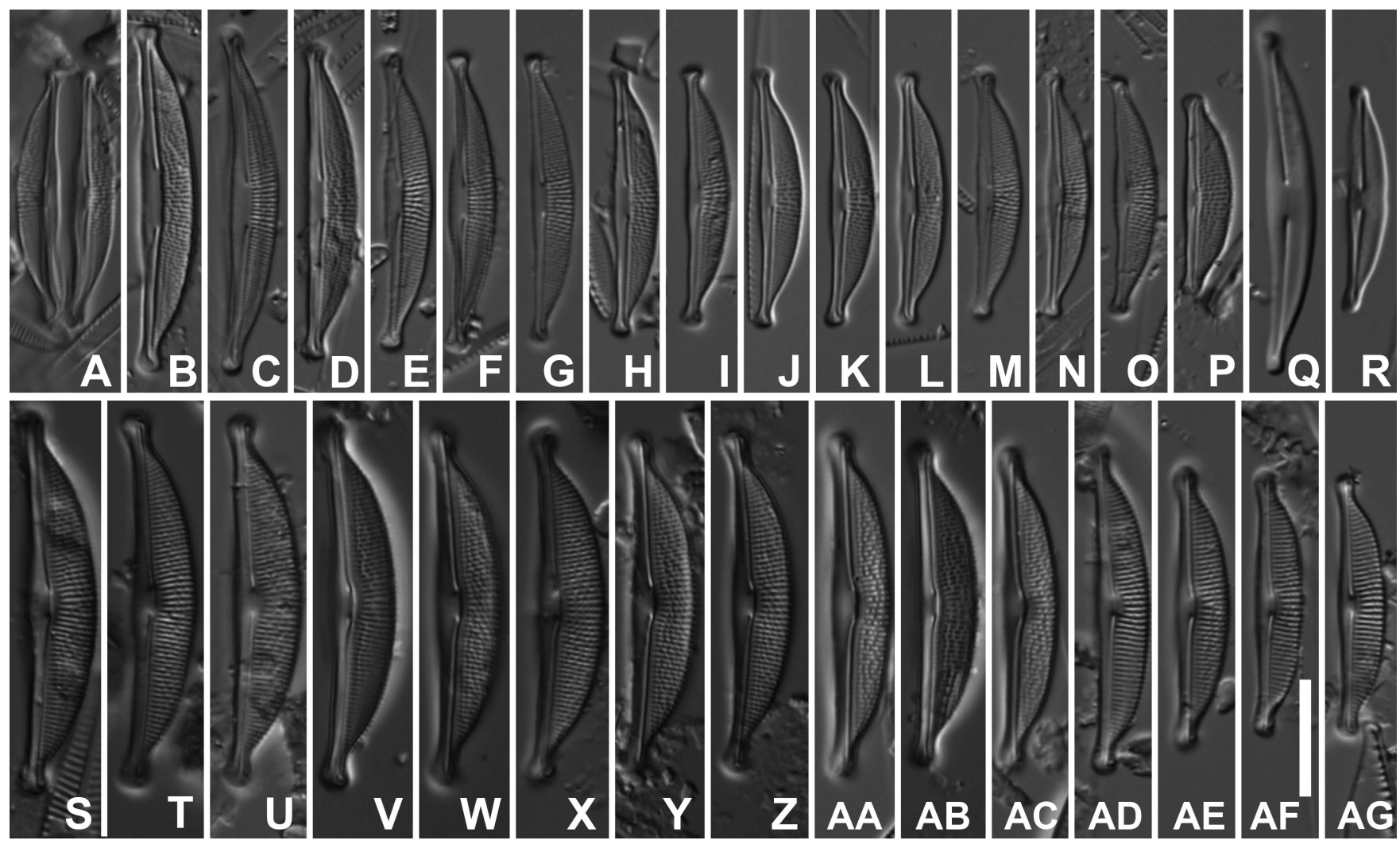

Figure 4 - Halamphora oligotraphenta (A-R) and H. ausloosiana (S-AG): A-R, LM micrographs of a population of $H$. oligotraphenta from James Ross Island (sample JRI-D032). A represents a frustule in girdle view; Q \& R represent so-called ghost valves; S-AG, LM micrographs of the population of $H$. ausloosiana from Livingston Island (sample LIV-BY049). Scale bar represents $10 \mu \mathrm{m}$.

\section{New taxa}

Halamphora ausloosiana Van de Vijver \& Kopalová, sp. nov.

Figs $4 \mathrm{~S}-\mathrm{AG} \& 6$

Type: holo-: BR-4370 (Botanic Garden Meise, Belgium); iso-: PLP-258 (University of Antwerp, Belgium), BRM-ZU9/75 (Hustedt Collection, Bremerhaven, Germany). - Type locality: Byers Peninsula, Livingston Island, South Shetland Islands, sample BY049 (62³8'43.1”S, 61 $\left.{ }^{\circ} 06^{\prime} 22.9^{\prime \prime} \mathrm{W}\right)$, (coll. B.Van de Vijver, coll. date 14 Jan. 2009).

LM: description - Valves semi-lanceolate, dorsi-ventral. Dorsal margin convex to almost straight (fig. 4Y, AA, AD \& $\mathrm{AF}$ ) in mid-valve, ventral margin straight (fig. $4 \mathrm{AB} \& \mathrm{AD}$ ) to weakly tumid in mid-valve (fig. 4E, Z, AE-AG). Valve ends distinctly set-off, slightly ventrally bent, sub-capitate in larger specimens to rostrate and slightly rounded in smaller specimens. Valve dimensions $(\mathrm{n}=25)$ : length $22-34 \mu \mathrm{m}$, valve width $4.0-6.5 \mu \mathrm{m}$. Axial area narrow, more expressed on the ventral valve side. Central area almost absent on the dorsal side, sometimes weakly semi-elliptical (fig. $4 \mathrm{U}, \mathrm{Z}, \mathrm{AD}, \mathrm{AF} \&$ AG), longitudinally elongated on the ventral side. Raphe biarcuate with slightly curved branches. Proximal ends distantly spaced, weakly expanded and slightly dorsally bent; distal fissures dorsally deflected. Dorsal striae showing a fine punctation in LM, 22-28 in $10 \mu \mathrm{m}$. Ventral striae indistinct, hard to resolve with LM, not interrupted in the region of the central nodule, 28-32 in $10 \mu \mathrm{m}$.
SEM: description, external and internal view - Transition between dorsal valve side and dorsal mantle abrupt (fig. 6A \& C). Raphe ledge flat, wide, linear, distinctly wider in mid-valve, without ornamentation (fig. 6A-C). Internal distal raphe endings slightly ventrally deflected terminating onto developed helictoglossae (fig. 6F). Proximally, raphe terminating onto fused central helictoglossae (fig. 6E). Dorsal striae biseriate throughout. Areolae appearing as "complex' with small circular foramina laying in two rows (fig. $6 \mathrm{D})$ giving them a biseriate character. Biseriate character of striae also internally clearly visible (fig. 6F). Recessed sieve plates present within areolae. Areolae internally occluded by hymenes. Ventral striae composed of one single elongated areola, becoming smaller near the central area (figs 6A \& C).

Etymology - The specific epithet 'ausloosiana' is given in honour of our late colleague and dear friend Dr. Gert Ausloos (Botanic Garden Meise), head of Public Awareness of the Botanic Garden who passed away too early on March $2^{\text {nd }}$ 2014.

Distribution and ecology - At present, $H$. ausloosiana has only been with certainty identified from the South Shetland Islands (Kopalová \& Van de Vijver 2013 as Amphora cf. veneta Kütz.). It is however very likely that the distribution of this species is much larger but due confusion with similar taxa such as $H$. veneta and $H$. oligotraphenta, it is distribution is unclear. It has so far not been recorded during the revision of $H$. cf. veneta populations from the Antarctic Continent (see below). On Livingston Island (South Shetland 


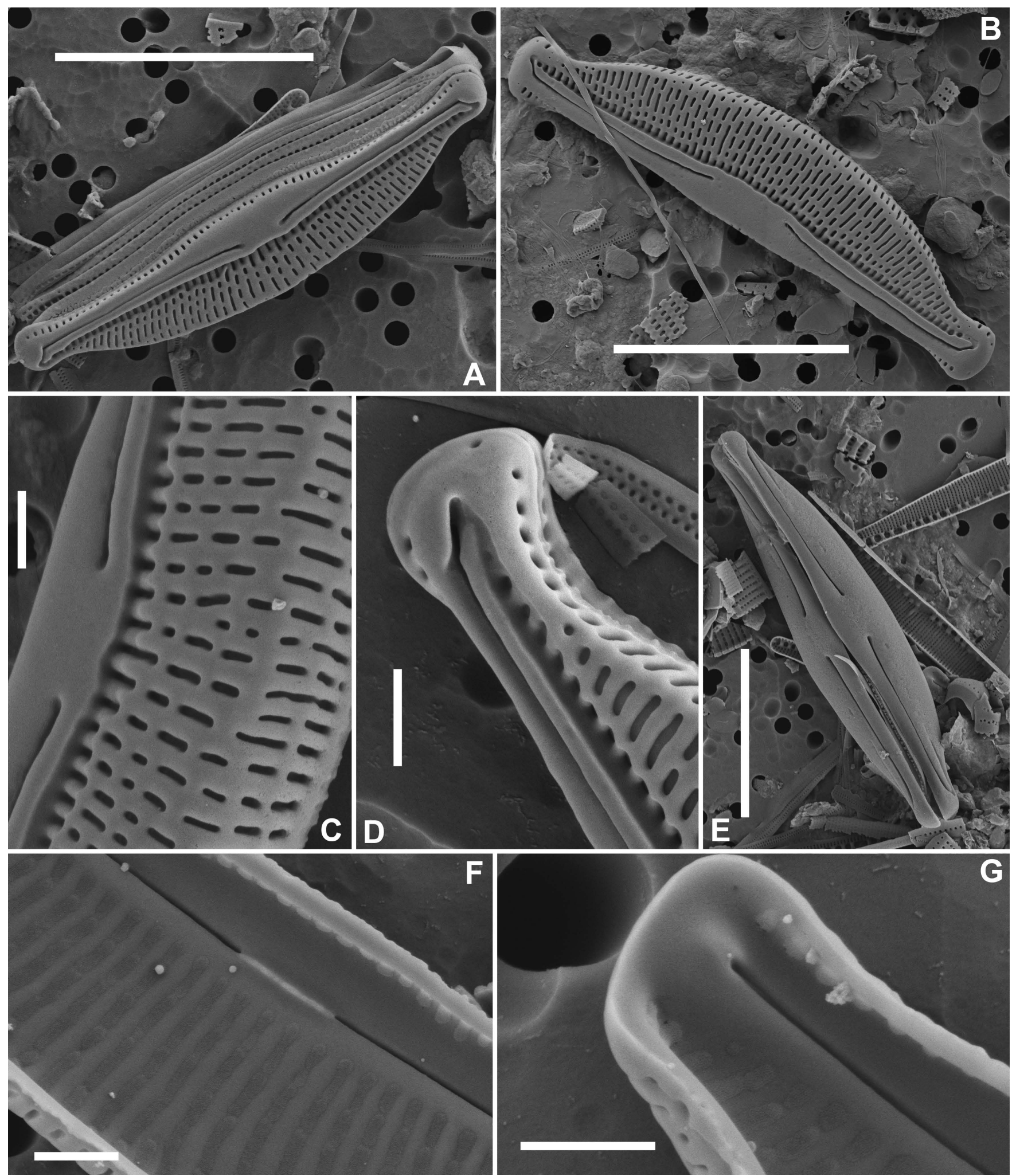

Figure 5-Scanning electron micrographs (SEM) of a population of Halamphora oligotraphenta from James Ross Island (sample JRI-D032): A, entire valve with parts of the girdle bands; B, entire valve; C, external detail of the central area with the proximal raphe endings; D, external detail of a valve apex with the distal raphe fissure; E, external view of an entire frustule of the so-called ghost-valves lacking any ornamentation apart from the raphe branches; F, internal detail of the central area with fused helictoglossae; G, internal detail of a valve apex. Scale bars represent $1 \mu \mathrm{m}$ except for A, B \& E where scale bars $=10 \mu \mathrm{m}$. 

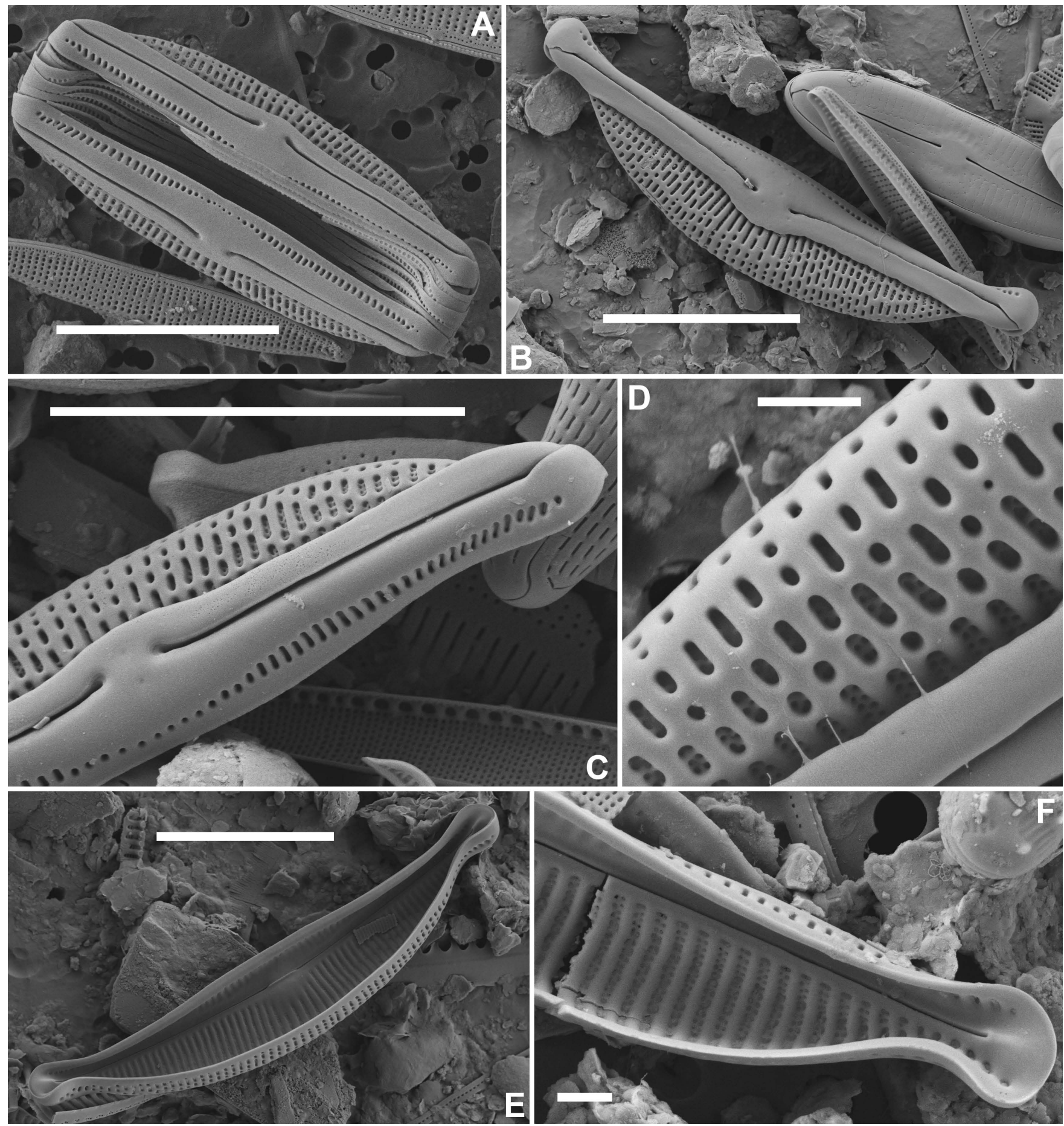

Figure 6 - Scanning electron micrographs (SEM) of the population of Halamphora ausloosiana from Livingston Island (sample LIVBY049): A, entire frustule with parts of the girdle bands; B, entire valve; $\mathrm{C}$, external detail of half a valve in oblique view showing the mantle striae composed of one single areola; D, external detail of the biseriate striae showing clearly the doubling of the areolae inside the striae ; E, internal overview of an entire valve with fused helictoglossae; F, internal detail of a valve apex with the covered biseriate striae. Scale bars represent $10 \mu \mathrm{m}$ except for $\mathrm{D} \& \mathrm{~F}$ where scale bars $=1 \mu \mathrm{m}$.

Islands), $H$. ausloosiana often forms rather large populations in the lakes and pools on Byers Peninsula. The type population was found in a small pool (10 $\mathrm{m}$ diameter) close to Limnopolar Lake. On one side of the pool water was dripping from a rock surface in the pool while on the other side, water was flowing out in a small braided river. The bottom was covered with fine sediment and larger pebbles. Thin algal mats were present in the pool. The pool had a rather alkaline $\mathrm{pH}$ (7.6) with a low specific conductance value $(58 \mu \mathrm{S} /$ $\mathrm{cm})$. Dominant taxa in the pool include Fragilaria capucina 
s.1., Planothidium frequentissimum (Lange-Bert.) Round \& Bukht. and an at present unidentified Staurosirella taxon.

Taxonomical remarks - Based on valve size and shape, Halamphora ausloosiana resembles $H$. coraensis (Foged) Levkov (Foged 1964: fig. 16/11, Levkov 2009: plate 107: figs 33-37), but can be differentiated from latter by the shape of the valve ends (capitate and dorsally bent in $H$. coraensis), the ventral margin (distinctly concave in $H$. coraensis) and the dorsal margin (strongly convex in H. coraensis). Halamphora acutiuscula (Kütz.) Levkov shares similar morphological features as $H$. ausloosiana such as the valve outline. Additionally, $H$. acutiuscula has a similar areola structure with recessed sieve plates within (Levkov 2009: plate 234: figs 1-4). Differences between these two species are based on several morphological features: The areolae in $\mathrm{H}$. acutiuscula have small round to slightly elongated external apertures, making the striae appearing as finely punctate. The proximal raphe fissures in $H$. acutiuscula are distinctly dorsally bent and positioned very closely to each other. The central nodule (central internal costae) in $H$. acutiuscula is inwards thickened and elevated compared to the rest of the valve.

Several Halamphora species with 'complex' areolae (areolae with recessed sieve plates) have been observed such as $H$. aponina (Kütz.) Levkov, H. ghanensis Levkov and $H$. sydowii (Cholnoky) Levkov (Levkov 2009). Halamphora aponina is characterized by narrower valves $(3.0-4.5 \mu \mathrm{m}$ vs. $4.0-6.5 \mu \mathrm{m})$, and entirely biseriate striae. Halamphora ghanensis has shorter valves $(24-27 \mu \mathrm{m}$ vs. $22-34 \mu \mathrm{m})$ and more finely punctated striae with lower stria density (14-16 vs. $22-28$ in $10 \mu \mathrm{m}$ ). In $H$. sydowii, a single row of areolae close to the raphe is bordered by an internal longitudinal rib. This feature is not present in the H. ausloosiana. Moreover, the proximal raphe fissures in $H$. sydowii are distinctly dorsally bent and positioned very closely to each other contrary to $H$. ausloosiana that has distant proximal raphe fissures. Differences between $H$. sydowii and $H$. ausloosiana can also be observed in the stria density (17-19 vs. 22-28 in $10 \mu \mathrm{m})$.

Halamphora oligotraphenta differs in lacking the biseriate striae and having narrower valves $(3.5-4.5 \mu \mathrm{m}$ vs. 4.0 $6.5 \mu \mathrm{m})$.

Halamphora compereana Van de Vijver \& Levkov, sp. nov. Fig. 7

Type: holo-: BR-4371 (Botanic Garden Meise, Belgium); iso-: PLP-259 (University of Antwerp, Belgium), BRMZU9/76 (Hustedt Collection, Bremerhaven, Germany). Type locality: Grand Tunnel, Île Amsterdam, TAAF sample

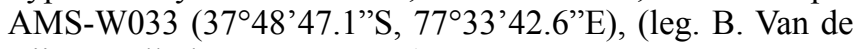
Vijver, coll. date 4 Dec. 2007).

LM: description - Valves semi-lanceolate with convex dorsal margin and weakly concave to weakly inflated in midvalve ventral margin. Valve apices distinctly set-off, capitate in larger specimens to rostrate in smaller specimens. Valve dimensions $(\mathrm{n}=15)$ : length $21-31 \mu \mathrm{m}$, width $4.0-5.5 \mu \mathrm{m}$. Central area on dorsal side variable in shape, rectangular (i.e. fig. $7 \mathrm{H} \& \mathrm{I}$ ) to semi-elliptical (i.e. fig. 7C, J, L \& N), bordered near the valve margin by $3-5$ central striae. Central area on the ventral side wide not distinctly separated from the axial area. Raphe ledge narrow, linear, distinctly wider near the valve ends, fused with the valve face in mid-valve. Raphe biarcuate with slightly curved raphe branches. Proximal ends clearly dorsally bent and distal ends dorsally deflected. Dorsal striae showing fine punctation in LM, radiate throughout, $19-21$ in $10 \mu \mathrm{m}$. Ventral striae indistinct, hard to resolve in LM, not interrupted near the central nodule 24-26 in $10 \mu \mathrm{m}$.

SEM: description, external and internal view - Transition between dorsal valve side and dorsal mantle abrupt (fig. 7P). Marginal ridge along the junction of valve face and dorsal margin absent (fig. 7P). Raphe ledge flat without ornamentation (fig. 7P \& R). Internally (fig. 7S), distal raphe endings slightly ventrally deflected, terminating onto developed helictoglossae. Proximal raphe endings terminating onto fused central helictoglossae. Dorsal striae biseriate throughout, towards the dorsal margin, striae becoming uniseriate (fig. 7P\& R). Areolae visible as 'complex' with small circular foramina arranged in two rows (7R). Recessed sieve plates present within the areolae which are clearly punctate (typically biseriate). Biseriate character of the striae also visible internally (fig. 7S). Areolae internally occluded by hymenes. Ventral striae composed of round to elongated areolae, smaller near the central area (fig. 7Q).

Etymology - This new species is dedicated to our dear colleague Pierre Compère (Botanic Garden Meise) on the occasion of his $80^{\text {th }}$ birthday.

Distribution and ecology - Halamphora compereana was found in a lava cavern on Ile Amsterdam, which is part of the partly collapsed Grand Tunnel, running from the Cratère de Vénus inférieur to the northern Indian Ocean coast. The sample was taken from the bottom of a small, shallow pool (diameter $30 \mathrm{~cm}$, maximum depth $5 \mathrm{~cm}$ ) at the end of a small cavern. The entire cavern is only sparsely illuminated and vegetated by mosses, liverworts and small ferns. The pool, part of a series of very small, probably temporary pools, was continuously fed by water dripping from the cavern's ceiling, with a $\mathrm{pH}$ of 5.8 and a specific conductance of $239 \mu \mathrm{S} \mathrm{cm}-1$. The sample was dominated by several Diadesmis species (among others D. vidalii Van de Vijver \& Ledeganck and D. crozetikerguelensis Le Cohu \& Van de Vijver), Planothidium subantarcticum Van de Vijver \& C.E.Wetzel, Karayevia oblongella (Østrup) Aboal, Melosira sp., Orthoseira verleyenii Van de Vijver, Sellaphora barae Van de Vijver \& E.J.Cox, Mayamaea cavernicola Van de Vijver \& E.J.Cox and Chamaepinnularia aerophila Van de Vijver \& Beyens.

Taxonomical remarks - Halamphora compereana resembles H. fontinalis (Hust.) Levkov. Both taxa share the same valve outline and size, but can be differentiated by the shape of the central area. The central area on the dorsal side in $H$. fontinalis forms a broad fascia reaching the dorsal margin (Hustedt 1937: figs 24: 4, 5; Sala et al. 2006: figs 4, 6, 8, Levkov 2009: plate 222: figs 1-5) whereas in H. compereana the central area is always bordered by shortened striae, therefore never forming a fascia. Halamphora rugosa (Hust.) Levkov has longer valves (35-47 $\mu \mathrm{m}$ vs. $21-31 \mu \mathrm{m}$ ) with a distinctly convex ventral margin. Further differences between $\mathrm{H}$. compereana and $H$. rugosa can be found in the position of the ventral striae, the shape of the central and axial areas, and the shape of the proximal raphe endings. Halamphora compereana has a comparable size as $H$. schroederi (Hust.) Lev- 


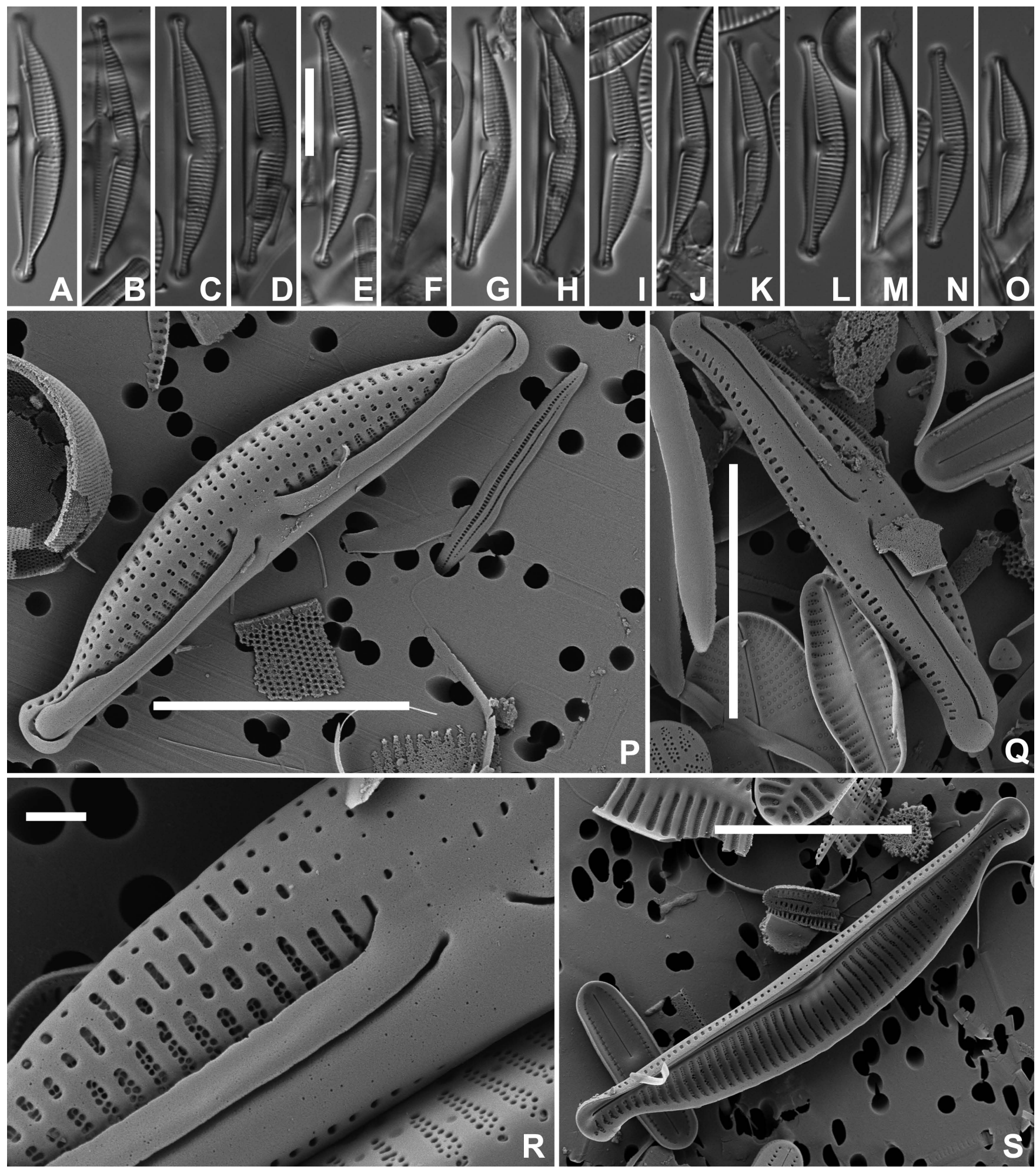

Figure 7 - Halamphora compereana: A-O, LM micrographs of the type population on Ile Amsterdam (sample AMS-W033); P, Scanning electron micrograph (SEM), entire valve with typical doubling of the areolae and the central area; Q, SEM, external view of a valve in oblique view showing the mantle areolae; R, SEM, external view of the central area showing the striae with a doubling of the areolae inside; S, SEM, internal overview of an entire valve. Scale bars represent $10 \mu \mathrm{m}$ except for $\mathrm{R}$ where scale bar $=1 \mu \mathrm{m}$. 
kov but can be differentiated from the latter by the shape of the central area on the dorsal valve side (Hustedt 1921: figs 16-18) which is absent in $H$. schroederi with the dorsal striae reaching the raphe ledge (partial conopeum sensu Levkov 2009). Additionally, in $H$. schroederi the internal virgae are strongly thickened, observable even with LM. From other taxa observed in the Antarctic and sub-Antarctic region, such as $H$. ausloosiana and $H$. oligotraphenta, $H$. compereana can be easily separated by the shape of the central area on the dorsal side and the proximal raphe endings. The central area on the dorsal side in H. ausloosiana and H. oligotraphenta is absent or almost absent, whereas in H. compereana it is rectangular to semi-elliptic in shape. Other differences include the proximal raphe endings that are distantly spaced and only slightly dorsally deflected in $H$. oligotraphenta and $H$. ausloosiana contrary to the clearly dorsally bent proximal raphe endings in H. compereana.

Halamphora dagmarobbelsiana Van de Vijver \& Levkov, sp. nov.

Fig. 8

Type: holo-: BR-4372 (Botanic Garden Meise, Belgium); iso-: PLP-260 (University of Antwerp, Belgium), BRMZU9/77 (Hustedt Collection, Bremerhaven, Germany). Type locality: Grand Tunnel, Île Amsterdam, TAAF sample

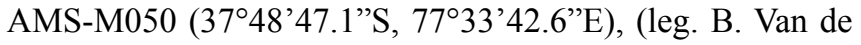
Vijver, coll. date 4 Dec. 2007).
LM: description - Valves semi-lanceolate with convex dorsal margin and weakly concave to straight ventral margin. Valve apices in larger specimens distinctly set-off, subcapitate and ventrally bent, in smaller specimens rounded and not separated from rest of valve. Valve dimensions $(n=13)$ : length 9-18 $\mu \mathrm{m}$, width $2.0-3.0 \mu \mathrm{m}$. Axial area very narrow, indistinct. Central area on both valve sides very small, semielliptical (fig. 8A \& D-F) to almost indistinct and hardly separated from the axial area. Raphe biarcuate with slightly curved raphe branches. Proximal endings slightly expanded, straight to weakly dorsally bent and distal fissures dorsally deflected. Dorsal and ventral striae not recognizable in LM.

SEM: description, external and internal view - Transition between dorsal valve side and dorsal mantle gradual. Marginal ridge along the junction of valve face and dorsal margin absent (fig. 8L). Raphe ledge broad, linear, without ornamentation and slightly wider near mid-valve (fig. 8K\& L). Raphe biarcuate with expanded and slightly dorsally bent proximal endings, distal fissures dorsally deflected (fig. $8 \mathrm{~K}$ \& L). Internally (fig. 8M), distal raphe endings straight, terminating onto weakly developed helictoglossae. Proximal raphe endings terminating onto fused central helictoglossae. Externally (fig. 8L), dorsal striae uniseriate throughout, 46-54 in $10 \mu \mathrm{m}$, composed of two transversally elongated to round areolae. Areolae near the valve margin appearing longer, due to a large portion of the first row of areolae next to the raphe being covered by the raphe ledge. Internally (fig. $8 \mathrm{M}$ ), areolae next to the raphe apparently longer and occluded by hymenes. Ventral striae (fig. 8K) composed of round
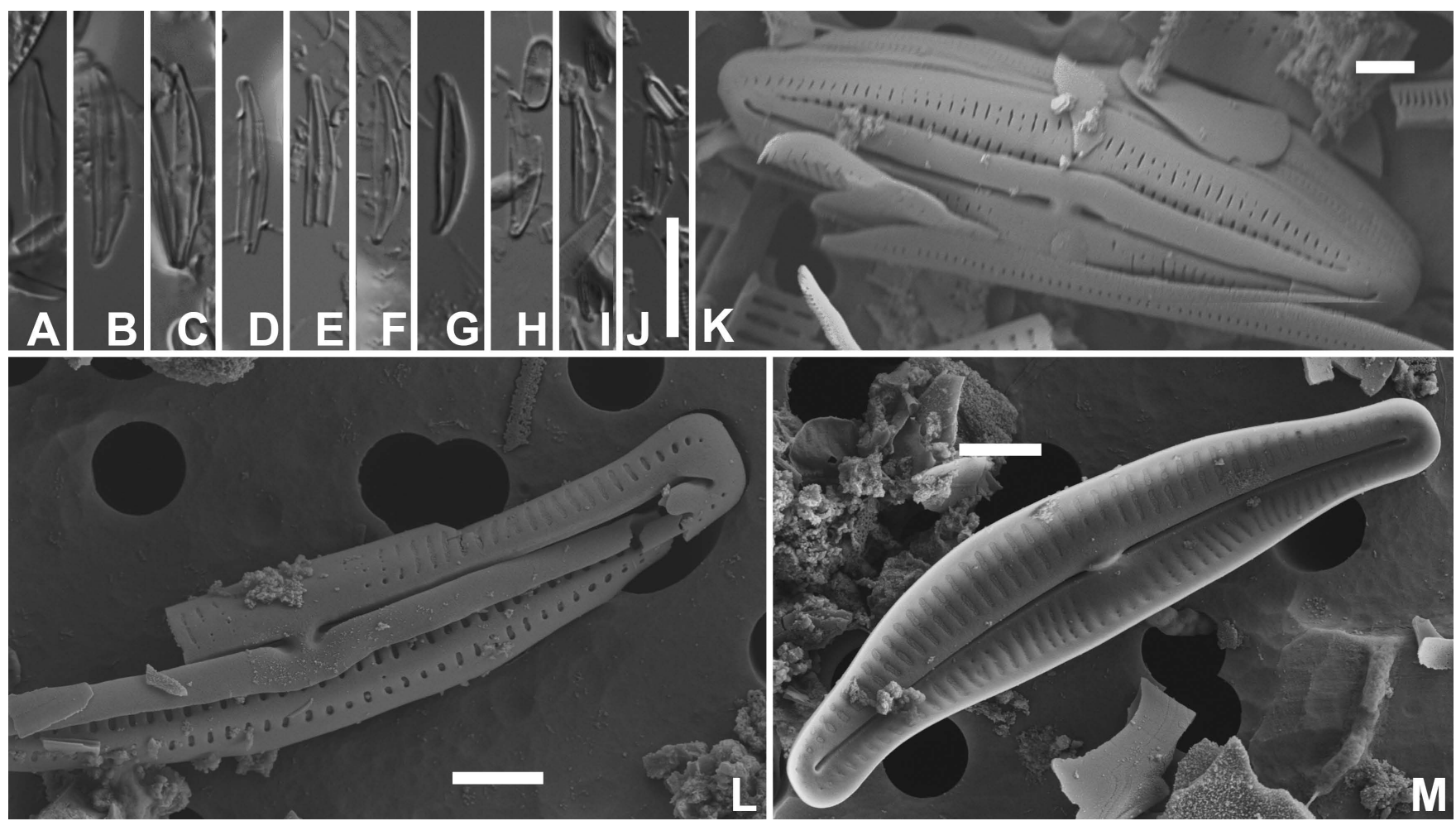

Figure 8 - Halamphora dagmarobbelsiana: A-J, LM micrographs of the type population on Ile Amsterdam (sample AMS-M050); K, Scanning electron micrograph (SEM), external detail of a frustule in oblique view showing the mantle and some girdle elements; L, SEM, entire (broken) valve showing the raphe course and the striae; M, SEM, internal overview of an entire valve. Scale bars represent $10 \mu \mathrm{m}$ except for $\mathrm{K}-\mathrm{M}$ where scale bars $=1 \mu \mathrm{m}$. 
Van de Vijver et al., Halamphora in the Antarctic Region

to elongated areolae, longer towards mid-valve, 54-60 in 10 $\mu \mathrm{m}$. In some specimens (fig. 8L) ventral areolae appearing as externally occluded. Near the central area ventral striae composed of small round areolae (fig. 8L).

Etymology - The new species is dedicated to Mrs. Dagmar Obbels (Ghent University, Belgium) in recognition of her algological work in the polar regions.

Distribution and ecology - The lava cavern in which Halamphora dagmarobbelsiana was found, is part of the partly collapsed Grand Tunnel, running from the Cratère de Vénus inférieur to the northern Indian Ocean coast. The sample was taken from mosses growing on the wall of the cavern, close to the entrance, in a population of the fern Blechnum australe $\mathrm{L}$. The sample was entirely dominated by a centric diatom species belonging at present to an undescribed new genus (Van de Vijver et al., unpubl. data), closely related to Melosira C.Agardh.

Taxonomical remarks - Halamphora dagmarobbelsiana has a unique set of characters (size, valve outline, shape of the central area and stria density) and is easy to distinguish from other species. Amphora micrometra Giffen (1967: figs $16,17)$ share some morphological features as H. dagmarobbelsiana such as valve size and stria density. Smaller valves of $H$. dagmarobbelsiana can be confused with A. micrometra, but clear differences can be noticed with SEM. The dorsal striae in A. micrometra are composed of a single elongated areola that continues on the valve mantle. The raphe ledge in A. micrometra is absent, opposite to H. dagmarobbelsiana where the raphe ledge on the dorsal valve side is well developed and thick. Additionally, a single portula-like opening is present in A. micrometra (see Ács et al. 2011: figs 19, 21, 24, 25), while such portula in $H$. dagmarobbelsiana is absent.

Amphora exilissima Giffen (1967: 251, fig 1: 8, 9) has a similar valve size (length 9-10 $\mu \mathrm{m}$; width $2.5-3 \mu \mathrm{m}$ ) as $H$. dagmarobbelsiana, but can be easily differentiated from the latter by the presence of a well-developed, conspicuous central stauros (see Ács et al. 2011: figs 13, 14). Amphora exilitata Giffen (1971: figs 5-7) has a similar valve size as H. dagmarobbelsiana (length $6-11 \mu \mathrm{m}$, width $2.5 \mu \mathrm{m}$ ) but most probably belongs to Amphora sensu stricto, since the girdle bands on the dorsal side are 'apparently simple' (Giffen 1971: 2). Images depicted in Witkowski et al. (2000: plate 164: figs 11-13) clearly show a species from the genus $\mathrm{Am}$ phora sensu stricto.

Two small-sized Amphora sensu lato taxa have been depicted in Rumrich et al. (2000): Amphora (?nov.) spec. sensu Rumrich et al. (2000: plate 123: figs: 15-18) and Amphora spec. sensu Rumrich et al. (2000: plate 123: figs 24, 25). Both taxa can be easily differentiated from $H$. dagmarobbelsiana by the shape of the central area and the stria density. Catenula adherens Mereschkowsky shows a similar valve size and stria morphology as $H$. dagmarobbelsiana, but can be easily distinguished from the latter by the position of the raphe (clearly observed in LM), its raphe structure and stria morphology. Lunella bisecta Snoeijs (Snoeijs 1996: 145, figs 1-34) has a similar appearance as H. dagmarobbelsiana, but can be easily differentiated by the raphe and stria morphology and structure (compare also with Witkowski et al. 2000: plate 170: figs 20-22).
Halamphora lateantarctica Van de Vijver, Kopalová, Zidarova \& Levkov, sp. nov.

Fig. 9

Type: holo-: BR-4373 (Botanic Garden Meise, Belgium); iso-: PLP-261 (University of Antwerp, Belgium), BRMZU9/78 (Hustedt Collection, Bremerhaven, Germany). Type locality: Lake 22, Bunger Hills, Antarctic Continent, sample BH-22 (66¹6’36”S, 10041’06”E), (leg. J.A.E. Gibson, coll. date 4 Dec. 2007).

LM: description - Frustules elliptic with truncate ends (fig. 9A). Valves semi-elliptical to nearly semi-circular in smaller specimens, dorsi-ventral with strongly convex dorsal margin and weakly concave (fig. 9B-D) to straight ventral margin (fig. 9E), sometimes weakly inflated in mid-valve (fig. 9G). Valve ends distinctly protracted and sub-capitate in larger specimens to weakly protracted and rounded in smaller specimens. Valve dimensions $(\mathrm{n}=25)$ : length $26-47 \mu \mathrm{m}$, width $7.0-10.0 \mu \mathrm{m}$, frustule width 13-21 $\mu \mathrm{m}$. Axial area narrow, more expressed on ventral valve side. Central area absent on dorsal side, longitudinally elongated on ventral side. Raphe ledge broad, widened at mid-valve tapering towards valve ends. Raphe biarcuate with slightly dorsally curved proximal endings. Proximal endings expanded into small distantly spaced central pores. Distal raphe fissures dorsally bent. Dorsal striae $22-28$ in $10 \mu \mathrm{m}$, with distinct punctation, radiate throughout. Ventral striae hard to resolve with LM, not interrupted in the region of the central nodule, 26-32 in $10 \mu \mathrm{m}$.

SEM: description, external and internal view - Transition between dorsal valve side and dorsal mantle abrupt (fig. 9I). Externally (fig. 9I), narrow, weakly thickened marginal ridge present along junction of valve face and dorsal margin. Marginal ridge more strongly thickened near poles. In some specimens raphe ledge ornamented with round or irregularlyshaped variable in size depressions which not penetrate internally (fig. 9I \& J). Dorsal striae uniseriate, composed of transversally elongated areolae (fig. 9I). Striae interrupted at marginal ridge and continuing on valve mantle. Ventral striae composed of transversally elongated areolae (fig. 9J). Size of areolae increases halfway from center to apex (fig. 9J). Internally (fig. 9K), internal costae (virgae) have the same width as striae, except central virgae which are wider. Internal distal raphe endings slightly ventrally deflected and terminate with developed helictoglossae. Proximal, raphe endings terminate with fused central helictoglossae. Five open girdle bands present, each bearing two rows of large, round poroids (fig. 9H).

Etymology - The specific epithet refers to the broad valve dimensions (Latin= 'late') and the distribution on the Antarctic Continent.

Distribution and ecology - Halamphora lateantarctica is a common species in East-Antarctica with confirmed records from the Windmill Island (Roberts et al. 2001), Amery oasis (Cremer et al. 2004), Bunger Hills (Gibson et al. 2006 as Amphora sp. g), Vestfold Hills (Van de Vijver, unpubl. res.) and most likely also from the Skarvsness ice free area (Ohtsuka et al. 2006, as Amphora sp., fig. 4). It is quite possible that the taxon is also present on other localities on the Antarctic Continent but confusion with Halamphora (Amphora) veneta obscures its distribution. The type population on Bunger 

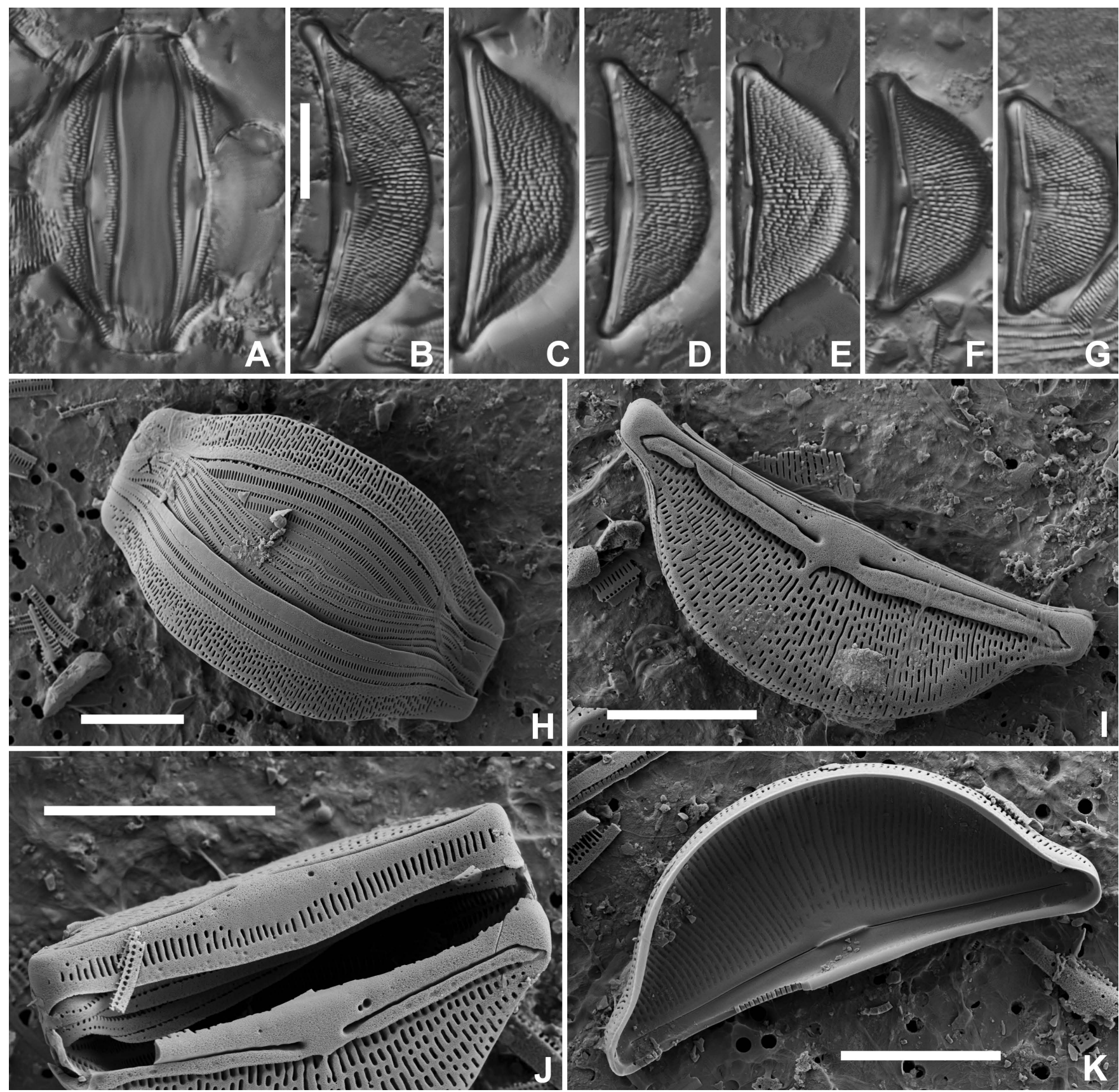

Figure 9-Halamphora lateantarctica: A-G, LM micrographs of the type population on Bunger Hills, Antarctic Continent (sample BH022). A represents a frustule in girdle view; $\mathrm{H}$, Scanning electron micrograph (SEM), external view of an entire frustule showing the girdle and the dorsal mantle; I, SEM, external view of an entire valve showing the raphe ledge and dorsal striae; J, SEM, detail of the ventral mantle and some girdle elements; K, SEM, internal view of an entire valve with the fused proximal helictoglossae Scale bars represent $10 \mu \mathrm{m}$.

Hills was collected from a rather large lake (length between 20 and $100 \mathrm{~m}$ ) covered with an orange-green benthic microbial mat. Other populations in the Bunger Hills were always sampled in low-salinity lakes (Gibson et al. 2006).

Taxonomical remarks - Halamphora lateantarctica resembles H. miroides Levkov (Levkov 2009: plate 109: figs 45-46; plate 220: figs 1-7) based on the valve shape, but differences can be observed in several ultrastructural features. In $H$. miroides the external openings of areolae are recessed showing a hexagonal shape. The areolae are partially occluded creating slit-like external foramina. The ventral striae near the central nodule are composed of 2-5 small round areolae, opposite to a single elongated areola in $H$. lateantarctica. Internally, the central virgae are strongly thickened, feature clearly visible also with LM. The marginal ridge in $H$. miroides is absent and the transition between dorsal valve side and dorsal mantle is gradual, contrary to the strongly thickened marginal ridge in $H$. lateantarctica that interrupts the dorsal striae. Another species that resembles H. lateantarctica is H. mira (Krasske) Levkov. However, the 
latter species has larger valves (length $40-80 \mu \mathrm{m}$, width 9-14 $\mu \mathrm{m})$, with longer and more subcapitate apices and a lower stria density (dorsal striae 17-21 in $10 \mu \mathrm{m}$; ventral striae 1824 in $10 \mu \mathrm{m}$ ). Additionally, H. mira is a brackish, subtropical species, opposite to $H$. lateantarctica which occurs in lowsalinity polar lakes. Halamphora lateantarctica can be easily differentiated from H. tucumana (Herbst \& Maidana) Levkov by the absence of strongly thickened virgae (Herbst \& Maidana 1988: figs 1-17).

Halamphora vyvermaniana Van de Vijver, Kopalová, Zidarova \& Levkov, sp. nov.

Figs $10 \& 11$

Type: holo-: BR-4374 (Botanic Garden Meise, Belgium); iso-: PLP-262 (University of Antwerp, Belgium), BRM-ZU9/79 (Hustedt Collection, Bremerhaven, Germany). -Type locality: Tarnya Lake 1a, Vestfold Hills, sample VH003, (leg. J.A.E. Gibson).

LM: description - Frustules broadly elliptical with short protracted and truncated ends (fig. 10A). Valves broadly semi-elliptical, dorsi-ventral with a strongly convex dorsal margin and weakly concave ventral margin, sometimes almost straight (fig. $10 \mathrm{~N}, \mathrm{~T} \& \mathrm{~V}$ ) to slightly inflated in the middle (fig. $10 \mathrm{H} \& \mathrm{U}$ ). Valve ends variable, long protracted and capitate in larger specimens to shortly subrostrate in mid- sized and small-sized specimens. Valve dimensions $(\mathrm{n}=22)$ : length 14-47 $\mu \mathrm{m}$, width 5-10 $\mu \mathrm{m}$. Axial area narrow, more expressed on the ventral valve side. Central area absent on the dorsal side, longitudinally elongated on the ventral side. Raphe ledge broad, widened at mid-valve tapering towards the valve ends. Raphe biarcuate with slightly expanded, straight to dorsally bent proximal endings. Dorsal striae radiate throughout, distinctly punctate, $24-30$ in $10 \mu \mathrm{m}$. Areolae in the mid-valve larger. Ventral striae indistinct, hard to resolve with $\mathrm{LM}, 28-32$ in $10 \mu \mathrm{m}$. Ghost valves often observed (fig. 10I).

SEM: description, external and internal view - Transition between the dorsal valve side and the dorsal mantle abrupt (fig. 11A-C). Distinct marginal ridge present along the dorsal margin (fig. 11B \& C). Raphe ledge broad, arched, elevated from valve face and ornamented with small, round depressions (fig. 11C \& D). Proximal endings expanded and slightly dorsally bent, distal fissures dorsally deflected (fig. 11 A \& C). Striae uniseriate, radiate throughout, composed of elongated areolae of different size (fig. 11C). Ventral striae placed on the ventral mantle, composed of a single areola and not interrupted near the central area (fig. 11A \& D). Areolae on the ventral striae slit-like, having a variable size, smaller towards the central area and the apices (fig. 11D). Dorsal and ventral girdle bands with a row of small, elongated poroids (fig. 11B \& C). Internally (fig. 11E), central virgae slightly
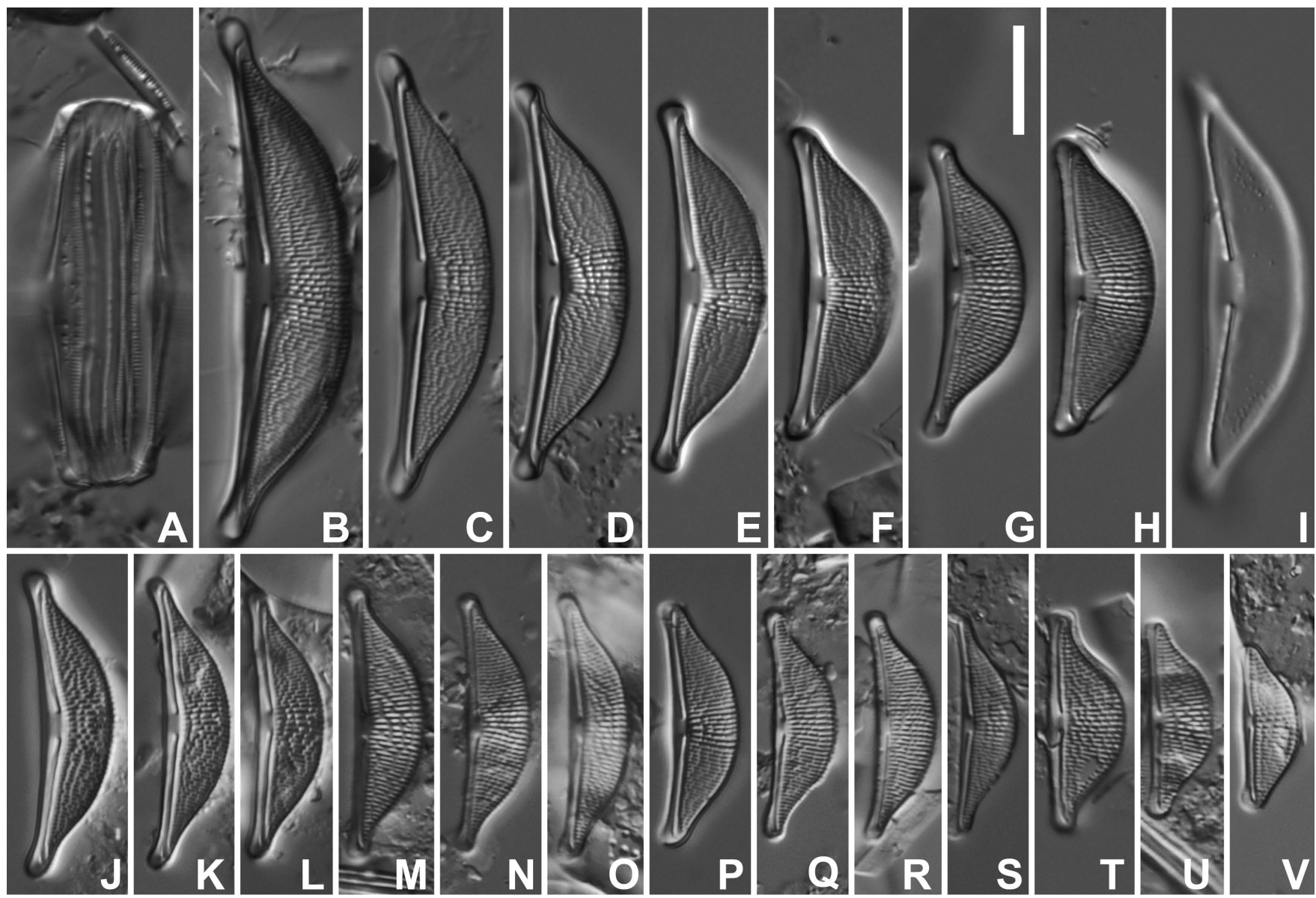

Figure 10 - LM micrographs of the type population of Halamphora vyvermaniana on the Vestfold Hills, Antarctic Continent (sample VH003). I represents a ghost valve. Scale bar represents $10 \mu \mathrm{m}$. 

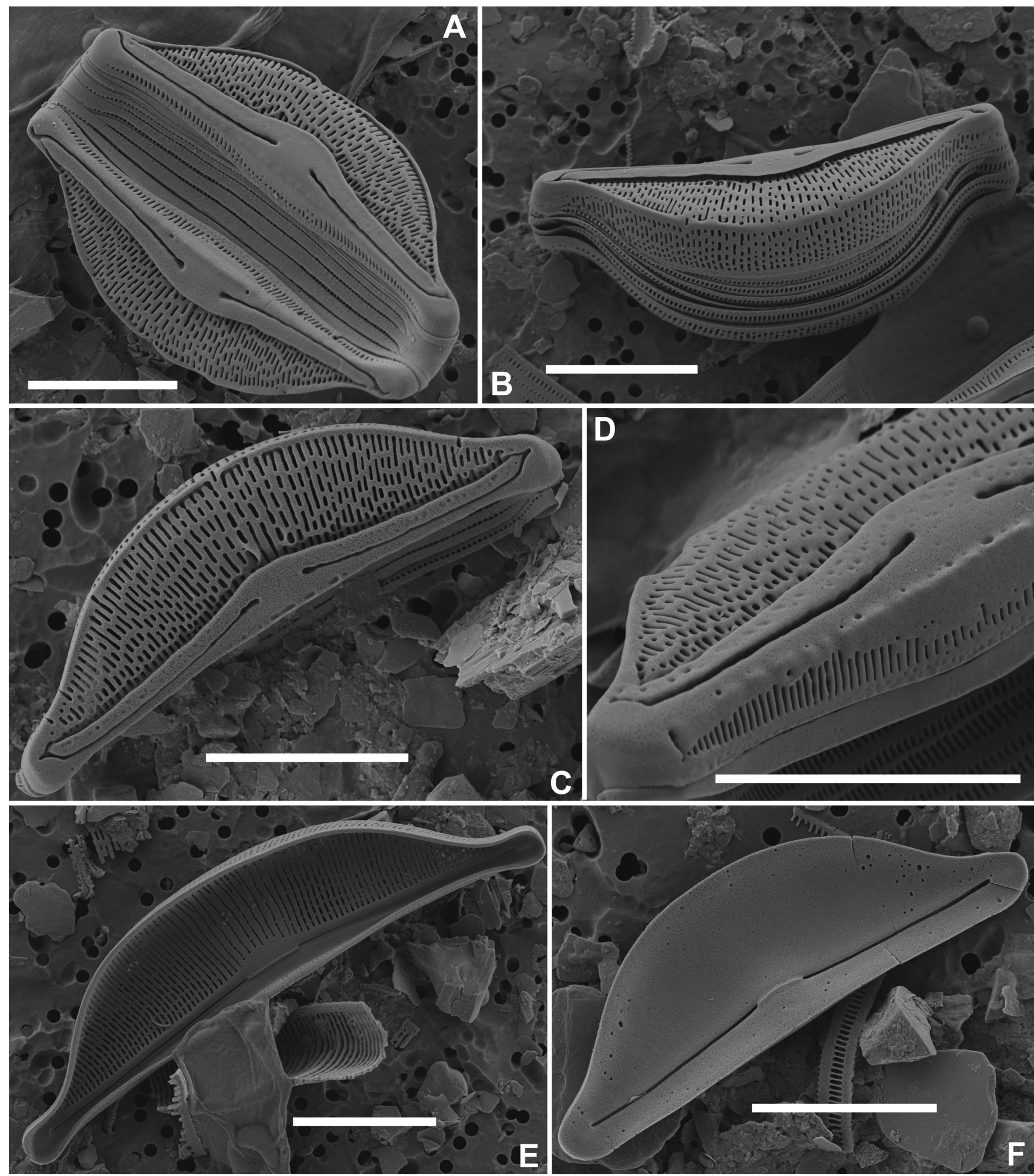

Figure 11 - Scanning electron micrographs (SEM) of the type population of Halamphora vyvermaniana on the Vestfold Hills, Antarctic Continent (sample VH003): A, entire frustule with parts of the girdle bands; B, entire valve seen from the dorsal side showing the dorsal mantle and the valve face/mantle margin; $C$, external view of an entire valve; $D$, external detail of ventral valve mantle showing the mantle areolae; E, internal view of an entire valve with fused helictoglossae; F, internal view of a heavily silicified valve ( ghost valve). Scale bars represent $10 \mu \mathrm{m}$. 
wider and thickened. Distal raphe endings straight, terminating onto poorly developed helictoglossae. Proximally, raphe endings distantly spaced and terminating onto fused central helictoglossae. Areolae occluded by hymenes. Typical heavily silicified ghost valves occasionally present (fig. 11F).

Etymology - The new species is dedicated to Prof. Dr. Wim Vyverman (Ghent University, Belgium) in recognition of his important contributions to the Antarctic algological research.

Distribution and ecology - Most literature records of Halamphora veneta from the Antarctic Continent most likely represent Halamphora vyvermaniana (e.g. Sabbe et al. 2003, Ohtsuka et al. 2006, see Kellogg \& Kellogg 2002 for more references). Outside the Antarctic Continent, the species has so far not been found. It is a common constituent of different lake ecosystems in Continental Antarctica.

Taxonomical remarks - Halamphora vyvermaniana apparently is a quite variable taxon regarding its valve outline and dimensions. All investigated populations show a similar morphological variability. This species was recorded by Ohtsuka et al. (2006: fig. 5) from freshwater lakes of Skarvsnes ice-free area, East Antarctica. However, almost all specimens depicted in Ohtsuka et al. (2006: figs 1-8), labeled as " $\mathrm{Am}$ phora sp." most probably belong to several different species, differing among each other with respect to mainly the valve shape and size but also to stria density. Whether they all belong to different species is at present unclear and molecular research most likely will be necessary to separate these morphologically different forms. Halamphora vyvermaniana has a similar outline and size compared to $H$. subcapitata (Kisselew) Levkov [= Amphora veneta var. subcapitata Kisselew (Kisselew1932: fig. 22)], but can be easily differentiated by the shape of valve apices (broadly rounded and not protracted in H. subcapitata) less pronounced central virgae and higher striae density (20-22 in $10 \mu \mathrm{m}$ in H. subcapitata). Additionally, the external foramina of poroids on girdle bands in H. subcapitata appear complex with elaborate invaginations (cf. Levkov 2009: plate 199: figs 5, 6). Larger specimens of $H$. vyvermaniana may be confused with smaller specimens of $\mathrm{H}$. mira, but the latter species has usually larger valves (length $40-80 \mu \mathrm{m})$ with lower striae density $(17-21$ in 10 $\mu \mathrm{m})$. Halamphora mira is has larger width than $H$. vyvermaniana (width 9-14 vs. 5-10 $\mu \mathrm{m}$ ) for any given valve length and possesses stronger curvature of the dorsal margin. Another species that resembles $H$. vyvermaniana is $H$. miroides (Levkov 2009: plate 109: figs 45-46; plate 220: figs 1-7). Halamphora vyvermaniana can be easily differentiated from the latter species by the morphology, structure and shape of areolae on the ventral striae and the less pronounced central virgae. From H. tucumana (Herbst \& Maidana) Levkov [=Amphora tucumana Herbst \& Maidana (Herbst \& Maidana 1988: figs 1-17)] it can be easily differentiated by the absence of strongly thickened virgae, which are clearly visible with LM. Amphora inaequistriata De Toni \& Forti (De Toni \& Forti 1913: 39-40, fig. 1), has more distantly spaced striae in the mid-valve and broadly rounded (not subcapitate) apices.

\section{BIOGEOGRAPHICAL REMARKS}

The taxonomic revision of the genus Halamphora with the description of five new species entirely changes our vision on the distribution of this genus in Antarctica. Whereas based on the literature list in Kellogg \& Kellogg (2002) H. veneta was considered a widespread, cosmopolitan taxon, its distribution in the Antarctic Region is now restricted to the sub-Antarctic islands. In the Maritime Antarctic Region, the species seems to be replaced by H. ausloosiana (South Shetland Islands) and $H$. oligotraphenta (James Ross Island). A reanalysis of the original material will be necessary to clarify whether the published records of $H$. veneta and $H$. oligotraphenta from the South Orkney Islands or the South Shetland Islands (e.g. Oppenheim 1990, Oppenheim \& Greenwood 1990, Håkansson \& Jones 1994) belong to either $H$. ausloosiana or $H$. oligotraphenta. For soil diatoms, it was already clear that a typical regionalization existed within the Antarctic Region as demonstrated by the high number of endemic taxa in the genera Luticola (e.g. Van de Vijver et al. 2011a, Kopalová et al. 2011), Hantzschia (Zidarova et al. 2010) and Muelleria (Van de Vijver et al. 2010, 2014). The revision of Halamphora confirms now that a similar regionalization is also present in aquatic genera, as was shown already for Stauroneis (Van de Vijver et al. 2005) or Navicula (Van de Vijver et al. 2011b), both typical lake ecosystem constituents.

\section{ACKNOWLEDGEMENTS}

Sampling on Crozet and Amsterdam has been made possible thanks to the logistic and financial support of the French Polar Institute-Paul-Emile Victor in the framework of the terrestrial program 136 (Marc Lebouvier \& Yves Frenot). Samples on Byers Peninsula were taken in the framework of the IPY-Limnopolar Project POL2006-06635 (Prof. Dr. Antonio Quesada, Ministerio de Ciencia y Tecnología, Spain). The authors would also like to thank the members of expeditions to the Czech J.G. Mendel Antarctic Station for field support and assistance. K. Kopalová benefited from grant GA UK grant nr. 394211. Part of the research was funded within the Belspo CCAMBIO project and an EU Synthesys grant to BVDV to visit the National History Museum in London, UK. Alex Ball, the staff of the EMMA laboratory and Eileen J. Cox at the Natural History Museum are thanked for their help with the scanning electron microscopy.

\section{REFERENCES}

Ács E., Ector L., Kiss K.T., Cserháti C., Morales E.A., Levkov Z. (2011) Morphological observations and emended description of Amphora micrometra from the Bolivian Altiplano, South America. Diatom Research 26: 199-211. http://dx.doi.org/10.1080/0 269249X.2011.597987

Carter R., Round F.E. (1993) Studies on freshwater Amphora species. V. Amphora montana and some rather similar forms. Diatom Research 8: 1-11.

Chattová B., Lebouvier M., Van de Vijver B. (2014) Freshwater diatom communities from Ile Amsterdam (TAAF, southern Indian Ocean). Fottea 14: 101-119.

Cleve P.T. (1895) Synopsis of the naviculoid diatoms, part II. Kongliga Svenska-Vetenskaps Akademiens Handlingar 27: 1-219. 
Cremer H., Gore D., Hultzsch N., Melles M., Wagner B. (2004) The diatom flora and limnology of lakes in the Amery Oasis, East Antarctica. Polar Biology 27: 513-531. http://dx.doi. org/10.1007/s00300-004-0624-2

De Toni G.B., Forti A. (1913) Contribution à la flore algologique de la Tripolitaine et de la Cyrénaïque. Annales de l'Institut Océanographique 5: 1-56.

Foged N. (1964) Freshwater diatoms from Spitsbergen. Tromsö Museums Skrifter, Universitetsførlaget 11: 1-204.

Gibson J.A.E., Roberts D., Van de Vijver B. (2006) Salinity control of the distribution of diatoms in lakes of the Bunger Hills, East Antarctica. Polar Biology 29: 694-704. http://dx.doi. org/10.1007/s00300-006-0107-8

Giffen M.H. (1967) Contributions to the diatom flora of South Africa IV. The marine littoral diatoms of the Estuary of the Kowie River, Port Alfred, Cape Province. Nova Hedwigia Beihefte 31: 259-312.

Giffen M.H. (1971) Marine littoral diatoms from the Gordon's bay, region of False Bay Cape Province, South Africa. Botanica Marina 14: $1-16$

Håkansson H., Jones V.J. (1994) The compiled freshwater diatom taxa list for the maritime region of the South Shetland and South Orkney Islands. In: Hamilton P.B. (ed.) Proceedings of the Fourth Arctic-Antarctic Diatom Symposium Workshop. Canadian Technical report of Fisheries and Aquatic Sciences 157: 77-83.

Haworth E.Y. (1974) Some problems of diatom taxonomy in Scottish Lake sediments. British Phycological Journal 9: 47-55.

Herbst N., Maidana N.I. (1988) Amphora tucumana sp. nov., a new species from Cumbres Calchaquies, Tucuman, Argentina. Diatom Research 3: 47-54.

Hustedt F. (1921) VI. Bacillariales. In: Schröder B. (ed.) Zellpflanzen Ostafrikas, gesammelt auf der Akademischen Studienfahrt 1910. Hedwigia 63: 117-173.

Hustedt F. (1930) Bacillariophyta (Diatomeae). In: Pascher A. (ed.) Die Süsswasser-Flora Mitteleuropas 10: 1-466. Jena, Gustav Fischer.

Hustedt F. (1937) Systematische und ökologische Untersuchingen über die Diatomeen-Flora von java, Bali und Sumatra nach dem material der Deutschen Limnologischen Sunda-Expedition. "Tropische Binnengewässer, Band VII". Archiv für Hydrobiologie, Supplement 15: 393-506.

Kellogg T.B., Kellogg D.E. (2002) Non-marine and littoral diatoms from Antarctic and sub-Antarctic locations. Distribution and updated taxonomy. Diatom Monographs 1: 1-795.

Kisselew I.A. (1932) Beitrage zur Mikroflora des sub-ostlichen Teiles des Lapter-Meeres. Institut Hydrologique Russe, Exploration des Mers Russes 15: 66-104.

Kopalová K., Nedbalová L., de Haan M., Van de Vijver B. (2011) The genus Luticola (Diadesmidaceae) in lakes of James Ross Island (Maritime Antarctic Region) with the description of five new species. Phytotaxa 27: 44-60.

Kopalová K., Veselá J., Elster J., Nedbalová L., Komárek J., Van de Vijver B. (2012) Benthic diatoms (Bacillariophyta) from seepages and streams on James Ross Island (NW Weddell Sea, Antarctica). Plant Ecology and Evolution 145: 190-208. http:// dx.doi.org/10.5091/plecevo.2012.639

Kopalová K., Van de Vijver B. (2013) Structure and ecology of freshwater benthic diatom communities from Byers Peninsula (Livingston Island, South Shetland Island). Antarctic Science 25: 239-253. http://dx.doi.org/10.1017/S0954102012000764
Kopalová K., Nedbalová L., Nývlt D., Elster J., Van de Vijver B. (2013) Diversity, ecology and biogeography of the freshwater diatom communities from Ulu Peninsula (James Ross Island, NE Antarctic Peninsula). Polar Biology 36: 933-948. http:// dx.doi.org/10.1007/s00300-013-1317-5

Lange-Bertalot H., Metzeltin D. (1996) Indicators of oligotrophy, 800 taxa representative of three ecologically distinct lake types. Iconographia Diatomologica 2: 1-390.

Lange-Bertalot H., Külbs K., Lauser T., Nörpel-Schempp M., Willmann M. (1996) Dokumentation und Revision der von Georg Krasske beschriebenen Diatomeen-Taxa. Iconographia Diatomologica 3: 1-358.

Levkov Z. (2009) Amphora sensu lato. Diatoms of Europa 5: 1-916.

Ohtsuka T., Kudoh S., Imura S., Ohtani S. (2006) Diatoms composing benthic microbial mats in freshwater lakes of Skarvness icefree area, East-Antarctica. Polar Bioscience 20: 113-131.

Oppenheim D.R. (1990) A preliminary study of benthic diatoms in contrasting lake environments. In: Kerry K.R., Hempel G. (eds) Antarctic Ecosystems: Ecological Change and Conservation: 91-99. Berlin, Springer-Verlag.

Oppenheim D.R., Greenwood R. (1990) Epiphytic diatoms in two freshwater maritime Antarctic lakes. Freshwater Biology 24: 303-314.

Patrick R.M., Reimer C.W. (1975) The diatoms of the United States exclusive of Alaska and Hawaii. Volume 2, Part 2. Entomoneidaceae, Cymbellaceae, Gomphonemaceae, Epithemaceae. Monographs of the Academy of Natural Sciences of Philadelphia 13: 1-213.

Roberts D., McMinn A., Johnston N., Gore D.B., Melles M., Cremer H. (2001) An analysis of the limnology and sedimentary diatom flora of fourteen lakes and ponds from the Windmill Islands, East Antarctica. Antarctic Science 13: 410-419.

Ross R., Cox E.J., Karayeva N.I., Mann D.G., Paddock T.B.B., Simonsen R., Sims P.A. (1979) An amended terminology for the siliceous components of the diatom cell. Nova Hedwigia Beiheft 64: 513-533.

Round F.E., Crawford R.M., Mann D.G. (1990) The diatoms: biology and morphology of the genera. Cambridge, Cambridge University Press, $747 \mathrm{pp}$.

Rumrich U., Lange-Bertalot H., Rumrich M. (2000) Diatomeen der Anden. Von Venezuela bis Patagonien/Feuerland. Iconographia Diatomologica 9: 1-649.

Sabater S., Tomas X, Cambra J., Lange-Bertalot H. (1990) Diatom flora of the Cape of Creus peninsula, Catalonia, N.E. of Spain. Nova Hedwigia 51: 165-195.

Sabbe K., Verleyen E., Hodgson D.A., Vanhoutte K., Vyverman W. (2003) Benthic diatom flora of freshwater and saline lakes in the Larsemann Hills and Rauer Islands, East-Antarctica. Antarctic Science 15: 227-248. http://dx.doi.org/10.1017/ S095410200300124X

Sala S.E., Sar E.A., Hinz F., Sunesen I. (2006) Studies on Amphora subgenus Halamphora (Bacillariophyta) : the revision of some species described by Hustedt using type material. European Journal of Phycology 41: 155-167.

Snoeijs P. (1996) The establishment of Lunella gen. nov. (Bacillariophyta). Diatom Research 11: 143-154.

Tyler P.A. (1996) Endemism in freshwater algae, with special reference to the Australian region. In: Kristiansen J. (ed.) Biogeography of freshwater algae. Hydrobiologia 336: 127-135. http:// dx.doi.org/10.1007/BF00010826 
Van de Vijver B., Beyens L. (1996) Freshwater diatom communities of the Strømness Bay area, South Georgia. Antarctic Science 8: 359-368. http://dx.doi.org/10.1017/S0954102096000533

Van de Vijver B., Frenot Y., Beyens L. (2002) Freshwater diatoms from Ile de la Possession (Crozet Archipelago, Subantarctica). Bibliotheca Diatomologica 46: 1-412.

Van de Vijver B., Gremmen N. J. M.. Beyens L. (2005) The genus Stauroneis (Bacillariophyceae) in the Antarctic region. Journal of Biogeography. 32(10): 1791-1798. http://dx.doi.org/10.1111/ j.1365-2699.2005.01325.x

Van de Vijver B., Mataloni G., Stanish L., Spaulding S.A. (2010) New and interesting species of the genus Muelleria (Bacillariophyta) from the Antarctic region and South Africa. Phycologia 49: 22-41. http://dx.doi.org/10.2216/09-27.1

Van de Vijver B., Zidarova R., de Haan M. (2011a) Four new Luticola taxa (Bacillariophyta) from the South Shetland Islands and James Ross Island (Maritime Antarctic Region). Nova Hedwigia 92: 137-158.

Van de Vijver B., Zidarova R., Sterken M., Verleyen E., de Haan M., Vyverman W., Hinz F., Sabbe K. (2011b) Revision of the genus Navicula s.s. (Bacillariophyceae) in inland water of the Sub-Antarctic and Antarctic with the description of 5 new spe- cies. Phycologia 50: 281-297. http://dx.doi.org/10.2216/1049.1

Van de Vijver B., Zidarova R., Kopalová K. (2014) New species in the genus Muelleria (Bacillariophyta) from the Maritime Antarctic Region. Fottea 14: 77-90.

Van der Werff A. (1955) A new method of concentrating and cleaning diatoms and other organisms. Verhandlungen Internationalen Vereinigung für Theoretische und Angewandte Limnologie 2: $276-277$.

Witkowski A., Lange-Bertalot H., Metzeltin D. (2000) Diatom flora of marine coasts I. Iconographia Diatomologica 7: 1-925.

Zidarova R. Van de Vijver B., Quesada A., de Haan M. (2010) Revision of the genus Hantzschia (Bacillariophyceae) on Livingston Island (South Shetland Islands, Southern Atlantic Ocean). Plant Ecology and Evolution 143: 318-333. http://dx.doi. org/10.5091/plecevo.2010.402

Manuscript received 14 Feb. 2014; accepted in revised version 10 Apr. 2014.

Communicating Editor: Elmar Robbrecht. 